\title{
A COMPARATIVE STUDY REGARDING THE LEARNING STYLES OF TURKISH UNDERGRADUATE GEOGRAPHY STUDENTS AND THEIR WESTERN COUNTERPARTS
}

\author{
Türkiye’deki Coğrafya Öğrencilerinin Öğrenme Stillerinin Batılı Emsalleriyle \\ Karşılaştırılması
}

\begin{abstract}
Nevin ÖZDEMIR ${ }^{1}$
ABSTRACT

It has been argued that culture has a significant impact on learning styles. Turkey is one of the nonWestern countries according to studies on the classification of countries based on cultural characteristics. Therefore, the primary objective of this study was to compare the learning styles of geography undergraduates in Turkey with the findings of a previous international study in which the learning styles of Western geography undergraduates were assessed. Kolb's Learning Styles Inventory was used as a measurement tool in order to facilitate this comparison, and 1275 Turkish geography undergraduates studying at eight universities in different geographical regions of Turkey responded to this inventory. The data obtained from the study were analyzed to compare the learning styles with those of Western geography undergraduates. According to the research findings, the assimilating and converging learning styles were favored between Turkish geography undergraduates, while the assimilating learning style was favored between Western geography undergraduates. Similar to Western counterparts, there are significant differences between demographic variables such as age and class of and predominant learning styles of Turkish geography undergraduates within 10 departments.
\end{abstract}

Keywords: Turkish geography undergraduates, cross-cultural learning styles, Kolb's Learning Style Inventory (LSI), Experiential Learning Theory (ELT).

\section{ÖZET}

Kültürün öğrenme stilleri üzerinde anlamlı bir etkisi olduğu ileri sürülmektedir. Kültürel özellikleri esas alarak yapılan ülkelerin sınıflandırmasıyla ilgili çalışmalara göre Türkiye, Batı Kültür Bölgesi içerisindeki ülkelerden biri olarak kabul edilmemektedir. Bu bağlamda çalışmanın amacı Türkiye'deki coğrafya öğrencilerinin öğrenme stillerini Batılı coğrafya öğrencilerinin öğrenme stilleriyle ilgili önceki bir çalışmanın bulgularıyla karşılaştırmaktır. Bu karşılaştırmayı kolaylaştırmak için karşılaştırma yapılan çalışmada da kullanılan Kolb Öğrenme Stilleri Envanteri veri toplama aracı olarak kullanılmıştır. Türkiye'nin farklı coğrafi bölgelerinde yer alan 8 üniversitenin, coğrafya ve coğrafya öğretmenliği bölümlerinde öğrenim gören 1275 öğrenci bu envanteri cevaplamıştır. Bu çalışmadan elde edilen veriler, coğrafyacıların öğrenme stilleri üzerine yapılmış önceki çalıșmanın sonuçlarıyla karșılaștııılmıștır. Araștırma bulgularına göre Türk coğrafya öğrencilerinin baskın öğrenme stilleri özümseme ve ayrıştırma olduğu, buna karşılık batılı emsallerinin baskın öğrenme stilinin özümseme olduğu sonucuna varılmıştır. Batılı emsallerine benzer şekilde coğrafya öğrencilerinin öğrenme stilleri üniversite, yaş ve sınıf düzeyine göre anlamlı farklılıklar göstermektedir.

Anahtar Kelimeler: Türk coğrafya öğrencileri, kültürlerarası öğrenme stilleri, Kolb Öğrenme Stilleri Envanteri (KÖSE), Deneyimsel Öğrenme Kuramı (DÖK)

\section{INTRODUCTION}

The number of foreign students enrolled at universities has increased over the last decade, especially in Western countries, such as the USA, UK, Germany, France and Australia, and this marketing of higher education services has become an important financial resource for many of these nations (Holtbrügge \& Mohr, 2010). In recent years, it is observed that the increase in the

\footnotetext{
${ }^{1}$ Yrd. Doç. Dr., Ondokuz Mayıs Üniversitesi Eğitim Fakültesi İlköğretim Bölümü, Sosyal Bilgiler Öğretmenliği ABD., nevino@omu.edu.tr.
} 


\section{F.Ü. Sosyal Bilimler Dergisi 2015-25/1}

number of students coming from different countries to Turkey for higher education. According to data from the Centre of Assessment, Selection and Placement (CASP) in Turkey, the number of foreign students registered in higher education is over 43,000 (ÖSYM, 2013). These trends can raise important problems related to the differences in educational contexts such as learning, teaching, curriculum and behaviors that may exist between countries or cultures (Eaves, 2011). Therefore, there is good reason to explore the nature of learning style preferences of individuals from different cultural backgrounds (Healey \& Jenkins, 2000).

The students in higher education usually prefer to study in academic disciplines that reflect their own skills and interests. The learning styles of students are consequently shaped by the learning environment of this discipline that they have chosen (Kolb, 1984). Education in an academic field for students is a continuing process of selection and socialization to the pivotal norms of the field governing criteria for truth and how it is to be achieved, communicated, and used (Kolb \& Kolb, 2005). In this context, students are encouraged to learn to think like a mathematician, to feel like a poet or to decide like a manager. Some previous studies were used Kolb's Learning Style Inventory (LSI) in this regard have confirmed that learning styles have been differentiated according to the particular field of education (social sciences, science, etc.) and profession (Kolb \& Kolb, 2005; Mainemelis, Boyatzis, \& Kolb, 2002). For example, the individuals with undergraduate majors in the arts, history, political science, English and psychology tend to have diverging learning styles, while those majoring in more abstract and applied areas, such as physical sciences and engineering, have converging learning styles. Those with accommodating styles have educational backgrounds in business and management, and individuals with assimilating styles tend to pursue courses in economics, mathematics, sociology and chemistry (Bradbeer, 1999; Kolb, Boyatzis, \& Mainemelis, 1999).

The investigators hold different views with regard to the classification of the science of geography. According to Leigh (2005), geography is a social science that emphasizes processes and systems using the scientific method. Becher and Trowler (2001) hold that physical geography may fall into the harder science group, whereas human geography may fall into the softer side of the social science/science divide. However, there are different opinions emerged in previous studies about the learning styles of geographers. For Kolb (1981), geography is an assimilative discipline; by contrast, Nulty and Barrett (1996) drew on the earlier work of Cullen, Pearson, Saha and Spear (1994) concluded that geography students are predominantly accommodating learners, while Healey, Kneale and Bradbeer (2005) reported that the dominant learning style of geography undergraduates was assimilating. In addition, Dunphy and Spellman (2009) examined the relationship between the perception of the 'value' of fieldwork and the learning styles of geography undergraduates studying in British universities. They reported that of undergraduates in their sample were approximately $36 \%$ accommodating, $27 \%$ assimilating, $20 \%$ converging and $17 \%$ diverging.

However, cross-cultural researches on learning styles have revealed that culture acts as a strong socialization agent (Barmeyer, 2004). And the differences in cultural socialization tend to influence learning preferences of individuals and to produce different learning styles (Yamazaki, 2005). In this context, several investigators have attempted to find empirical evidence to support learning style variations on the basis of cultural backgrounds (Joy \& Kolb, 2009). A number of comparative studies used different measuring tools found significant differences in the learning style preferences among undergraduates from different countries, who were studying the same or different academic areas, and reported that culture had a significant impact on learning styles (e.g. Auyeung \& Sands, 1996; Apfelthaler, Hansen, Keuchel, Neubauer, Ong, Tapacha1, \& Mueller, 2005; Barmayer, 2004; Joy \& Kolb, 2009; Holtbrügge \& Mohr, 2010; House, Hanges, Javidan, Dorfman, \& Gupta, 2004; Boland, Sugahara, Opdecam, \& Everaert, 2011; Yamazaki, 2005). All these studies have been provided valuable empirical evidence related to the impact of culture on learning. 
However, it is advisable to take a careful look at designs of these studies and findings from these studies before associating certain countries or cultures with specific learning styles. About comparison of effect of culture and demographic variables in dominant learning styles, Joy and Kolb (2009) emphasized that "the area of specialization that one of the demographic variables seems to have a slightly larger effect on determining a person' and their liking for abstraction or concreteness than does culture. This may be because educational specialties are particularly focused on the development of, and socialization into, the ways of learning required to meet the performance demands of the discipline. In the case of culture, the socialization may be more indirect with respect to learning. Level of education appears to have as much of an effect as culture and gender slightly less (p.83)."

In this regard, Fridland (2002) suspected that academic specialization might have more influence on learning than culture. Fridland investigated differences between the learning styles of Chinese and American teachers by using the data obtained from the LSI. The results of his research revealed that there were no significant differences between the learning styles of both groups, and that the diverging learning style was the most preferred learning style in both groups. This would help to explain the results obtained by Zualkernan, Allert and Qadah (2006) who found no difference in the learning styles of Middle Eastern and American computer programming students.

An international research conducted by Healey, Kneale and Bradbeer (2005) using geography undergraduates from 12 universities in Australia, New Zealand, the USA and the UK was the first comprehensive study related to learning styles of geographer or geography undergraduates. However, any research related to the learning styles of geography undergraduates in a non-Western country or a comparative study of learning styles of non-Western and western geography undergraduates has until now been included in the cross-cultural literature on learning styles. It is expected that the present research assessing the learning styles of geography undergraduates in Turkey, which is located in the Middle East cultural zone according to the Global Leadership and Organizational Effectiveness (GLOBE) classification (Javidan, Dorfman, Sully, \& House, 2006), will contribute to future research on culture and learning styles. The present study was inspired by the following suggestions in two previous studies:

'However, the characteristic learning styles of geography students remain unclear. It is important that we establish whether geography students in higher education in the early twenty-first century have a predominant learning style and whether this varies between countries and the stage students are in their studies' (Healey \& Jenkins, 2000, p.193).

'Do the learning styles of geographers change during their degree courses? Do the learning styles of geographers in non-Western countries differ from those in AngloAmerica and Australasia?' (Healey, Kneale \& Bradbeer, 2005,p. 40)

In accordance with the recommendations of these authors, this study focused on determining the dominant learning styles of Turkish geography undergraduates and on compared these findings with those related to learning styles of western geography undergraduates in Healey et al. (2005). As in Healey et al. (2005) Kolb's LSI was used as measurement tool to facilitate this comparison. The data obtained from the study were analyzed on the basis of some key demographics, including university, gender, age and year of study. However, this international comparison is not statistically meaningful, so it is not possible to analyze data from both studies together. Nevertheless, the findings will provide empirical data related to the learning styles of geography undergraduates.

\section{Kolb's Experiential Learning Theory (ELT) and Learning Styles}

Theoretical and experimental studies related to learning theories and learning styles conducted over a period of over 40 years in the UK, the USA and Western Europe have led to the emergence of an extensive literature base. Coffield, Moseley, Hall and Ecclestone (2004) examined over 800 


\section{F.Ü. Sosyal Bilimler Dergisi 2015-25/1}

studies about learning styles as part of their project in 2002, and they were classified to theories concerning learning styles in these studies. Furthermore, the studies in the field of learning styles have also been comparatively analyzed by Given (1996), Lemire (1996), Cassidy (2004) and Hadfield (2006).

It was understood from these comparative studies that definitions of learning styles are also abundant as much as theories on learning styles (De Bello, 1990). The learning style terms used by various authors were classified and analyzed by Kazu (2009). On the basis of this study, some authors (e.g., Keefe, 1987; Dunn \& Dunn, 1993) have defined learning styles as the sum of the learner's characteristics originating from individual differences in the learning environment. For others (e.g. Entwistle, 1981; Kolb, 1984), learning style is a type of inner programme that shapes our behavior. Yet others (e.g. Jonassen \& Grabowski, 1993; Felder \& Silverman, 1988) suggested that individual tendencies to act in a specific way can be considered as 'preferences' that are closely related to individual differences. Despite these differences in, as Healey et al. (2005) states, 'a consensus emerges that the learning style should be defined in terms of a distinctive and habitual way an individual acquires knowledge, skills or attitudes and that, in adults, it is a relatively stable trait (p.31).'

One of the most well-known learning theories is the Experiential Learning Theory (ELT) developed by David Kolb (Kolb \& Kolb, 2005). This learning model has received particular attention especially with regard to the examination of cross-cultural activities (Hoppe, 1990). Kolb's theory states that the learning process is not to be same for everybody as a result of heredity, past life experiences and demands linked to environmental circumstances. Consequently everybody enhances an individual learning style with its strengths and weaknesses (Jonassen \& Grabowski, 1993). Kolb has put forward a comprehensive theory to develop a holistic model of the experiential learning (Kolb, 1984). ELT defines learning as 'the process whereby knowledge is created through the transformation of experience. Knowledge results from the combination of grasping and transforming experience (Kolb, 1984, p. 41).' Specifically Kolb described two main dimensions to learning that correspond to the two ways we learn; these are called the ConcreteAbstract dimension and the Active-Reflective dimension. Thus a person's preferred learning patterns measured along these two axes defining on the Learning Style Grid and the components of these two dimensions identifies one's learning style.

The Concrete-Abstract dimension, in Figure 1 it shown on the vertical axis of the Learning Style Grid, represents how we perceive information. Learners who rely more on tangible qualities such as sensing, feeling, and intuition, usually favor Concrete Experience as the favored means of receiving new information (Kolb, 1984). This preference also stresses an inclination for personal involvement with people in daily situations. In a learning setting, learners who prefer this mode would be more open minded, flexible, and adaptable to change. Learners who rely on Abstract Conceptualization usually step back and think about the new learning situation, analyze, and systematically plan rather than use their senses as a guide. In the Abstract Conceptualization stage, a person's learning involves using logic and ideas, rather than feeling, to understand problems or situations. Typically, this learner relies on systematic planning and develops theories to solve problems. These learners logically analyze ideas, systematically plan, and act on their intellectual understanding of the situation. This type of learner needs time to analyze the information presented.

After the learner acquires new information in the Concrete-Abstract dimensions, modes, it must be processed. Processing takes place in the second dimension of learning, the ActiveReflective Dimension, represented in Figure 1 on the horizontal axis (Kolb, 1984, Massey, Kim, \& Mitchell, 2011). In the Active-Reflective dimension, learners may choose to actively participate in learning (Active Experimentation) while other learners may prefer to watch others who are involved in the new learning experience (Reflective Observation) (Kolb \& Kolb, 2005). This process is portrayed as an idealized learning cycle or spiral, whereby the learner 'touches all the 
bases' - experiencing, reflecting, thinking, and acting - in a recursive process that is responsive to the learning situation and what is being learned.

In 1971, David Kolb developed a simple scale called the LSI to evaluate individual orientations for learning. The Learning Style Inventory is designed to measure the degree to which individuals display the different learning styles derived from experiential learning theory (Kolb, 1984). Each of these four learning styles is a component of two learning modes (Figure 1). Four learning styles are defined as a measure by combining the scores from a person's Concrete Experience/Abstract Conceptualization (CE/AC) modes and their Reflective Observation/Active Experimentation (AE/RO) modes. These four styles are called Diverging (CE / RO), Assimilating $(\mathrm{RO} / \mathrm{AC})$, Converging $(\mathrm{AC} / \mathrm{AE})$, and Accommodating (AE/CE). Thus a person's preferred learning style can be measured and displayed on a Learning Style Grid.

\section{Accommodating group}

- learn primarily from 'hands-on' experience.

- carry out plans and try new and challenging

experiences.

- tend to act on intuition rather than on logical analysis.

- rely more heavily on people for information than on own technical analysis.

- when learning, prefer to work with others to get assignments done, to set goals, to do field works, and to test out different approaches to completing a project.

- careers: organizations and business.

\section{Diverging group}

- view concrete situations from many different points of view.

- observe rather than take action.

- like to generate a wide range of ideas, fond

of brainstorming sessions.

- have broad cultural interest and like to gather information.

- imaginative ability and sensitivity to feelings.

- when learning, prefer working in groups to

mind, and receiving personalized feedback.

- careers: social service and arts and communications professions.

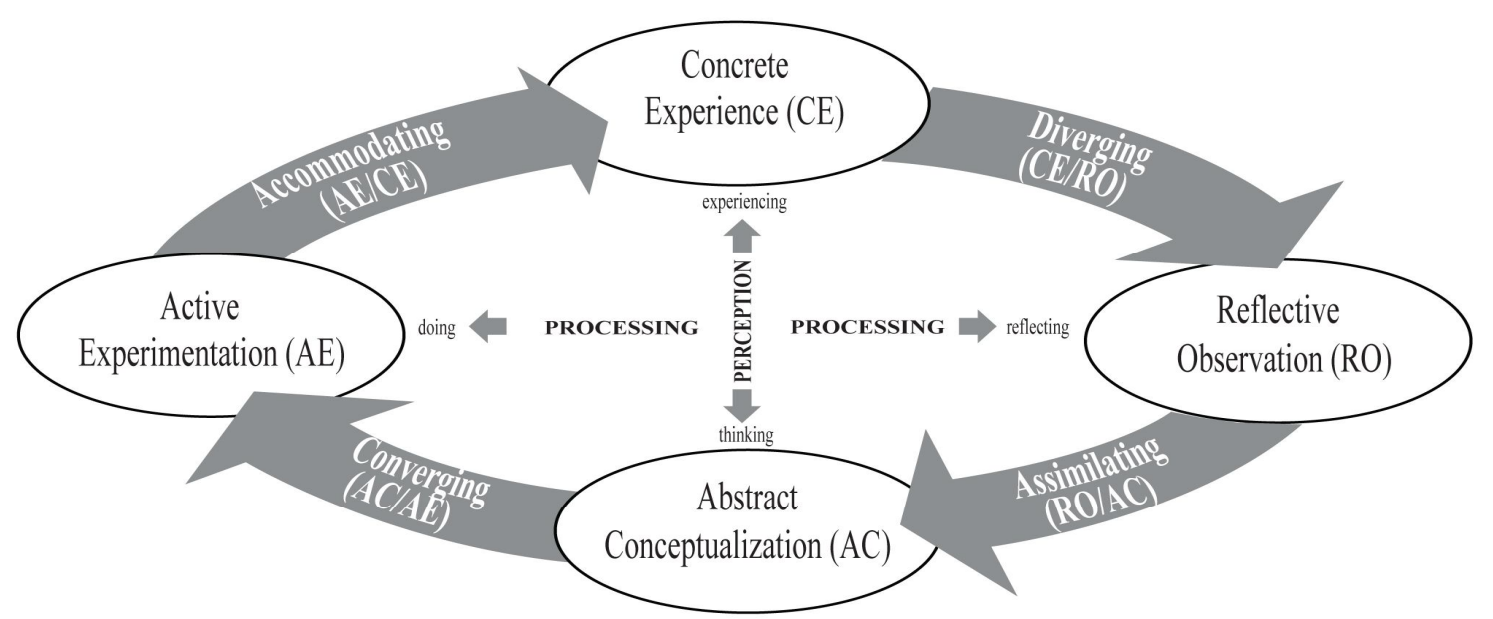

\section{Converging group}

- find practical uses for ideas and theories.

- solve problems and make decisions based on

finding solutions to questions or problems.

- prefer technical tasks and problems to social

and interpersonal issues.

- when learning, prefer to experiment with new ideas, simulations, laboratory assignments, and practical applications.

- careers: technology, economics, and environment science.
- can understand a wide range of information and put it into concise, logical form.

- less focused on people and more interested in abstract ideas and concepts.

- value a learning, prefer lectures, readings, exploring analytical models, and having time to think things through.

- careers: sciences, information science, and research.

Figure 1. Experiential Learning Thory and Characteristics of Kolb's Learning Styles (adapted from Kolb, 1984; Kolb et al., 1999). 


\section{METHODS}

As stated in the introduction part, this study focused on determining the dominant learning styles of Turkish geography undergraduates and on compared findings of this study with those of Healey et al. (2005). In the framework of this basic purpose, the sub-problems of research are following:

1- What are the dominant learning styles of geography undergraduates in Turkey?

2- How are the differences or similar aspects of learning styles when comparison Turkish and Western geography undergraduates?

3- Are there significant differences between the predominant learning styles of Turkish geography undergraduates according to some demographics (university, age, and gender and study year).

4- How are the differences or similar aspects of learning styles of Turkish and Western geography undergraduates according to some demographics (university, age, and gender and study year).

The higher education geography departments in Turkey were located in the science and arts faculties of universities, the departments of geography teaching of education faculties and the Faculty of Humanities in Ankara University. At present, there are 25 geography departments and eight geography teaching departments in total (İlhan, Gülersoy, \& Gümüş, 2013). Five departments of geography and five departments of geography teaching from eight universities located in different geographical regions of Turkey were randomly selected for this research, and it was taken into consideration to distribution of gender and age, and year of study of respondents. In the academic calendar year in which this study was conducted (2009-2010), the total number of geography undergraduates in Turkish universities was 8,046 (ÖSYM, 2011), and approximately 16 $\%$ of that total constituted the sample of the present study.

To compare our results with the data obtained by Healey et al. (2005), we used version 3 of the LSI (LSI 3) as the data collection tool. The studies on the psychometric features of the original LSI in 1971 led to the inventory that was first revised in 1985. The second version of the LSI (LSI 2) was translated into Turkish and tested for reliability by Aşkar and Akkoyunlu (1993). Continued validity and reliability studies led to a review of the inventory in 1993 (version 2a), in 1996 (version 3) and in 2005 (version 3.1) (Kayes, 2002; Kolb \& Kolb, 2005). The final changes to the third version of the inventory in 1996 (LSI 3) were made to concretize expressions. Cronbach's alpha coefficient for Kolb's LSI version 3 was reported as .70 on the basis of the average of seven different studies (Kolb \& Kolb, 2005). Translation of LSI 3 into Turkish and reliability studies were conducted by Gencel (2007), and it was noted that reliability coefficients for the dimension of learning style of the inventory changes are between 0.71 and 0.80 in this research,.

In a similar manner to Healey et al. (2005), the Chi-square test was used in the analysis of the data. As Joy and Kolb (1999) stressed, 'the general method of analysis used in the culturelearning style studies is a Chi-square test on the learning style types or a one-way ANOVA on the learning modes or the combination scores (p.33).' In this context, the one-way ANOVA method was used for assessing significant difference in learning styles between universities.

\section{FINDINGS}

1- The dominant learning styles of geography undergraduates in Turkey and a comparison with their Western counterparts:

As shown in Table 1, in the fall semester of 2009-2010, 1,275 Turkish geography undergraduates from 10 geography departments responded to the LSI 3 . The overall sample consisted of 57\% males and $43 \%$ females. In Turkey, the duration of undergraduate study is 4 years in departments of geography and 5 years in departments of geography teaching. The sample consisted of students from every class year, and they ranged in age from 17 to 27 years. 
A Comparative Study Regarding The Learning Styles of ...

Table 1. The key demographics of Turkish geography undergraduates

\begin{tabular}{|c|c|c|c|c|c|c|c|c|}
\hline & \multirow[b]{2}{*}{ University } & \multirow[b]{2}{*}{ City } & \multirow{2}{*}{\multicolumn{2}{|c|}{ Faculty }} & \multicolumn{2}{|c|}{ Gender } & \multicolumn{2}{|l|}{ Total } \\
\hline & & & & & $\mathbf{M}$ & $\mathbf{F}$ & No & $\%$ \\
\hline 1 & Ankara University & Ankara & \multicolumn{2}{|c|}{ Faculty of Humanities } & 51 & 49 & 100 & 8 \\
\hline 2 & Atatürk University & Erzurum & \multicolumn{2}{|c|}{ Faculty of Letters } & 87 & 64 & 151 & 12 \\
\hline 3 & Ondokuz Mayıs University & Samsun & \multicolumn{2}{|c|}{ Faculty of Science and Letters } & 110 & 60 & 170 & 13 \\
\hline 4 & Onsekiz Mart University & Çanakkale & \multicolumn{2}{|c|}{ Faculty of Science and Letters } & 85 & 51 & 136 & 11 \\
\hline 5 & Kocatepe University & Afyon & \multicolumn{2}{|c|}{ Faculty of Science and Letters } & 100 & 91 & 191 & 15 \\
\hline 6 & Gazi University & Ankara & \multicolumn{2}{|c|}{ Faculty of Education } & 47 & 52 & 99 & 8 \\
\hline 7 & Atatürk University & Erzurum & \multicolumn{2}{|c|}{ Kazım Karabekir Faculty of Education } & 117 & 69 & 186 & 15 \\
\hline 8 & Dicle University & Diyarbakır & \multicolumn{2}{|c|}{ Ziya Gökalp Faculty of Education } & 39 & 26 & 65 & 5 \\
\hline 9 & Dokuz Eylül University & İzmir & \multicolumn{2}{|c|}{ Buca Faculty of Education } & 54 & 53 & 107 & 8 \\
\hline \multirow[t]{3}{*}{10} & Onsekiz Mart University & Çanakkale & \multicolumn{2}{|c|}{ Faculty of Education } & 41 & 29 & 70 & 6 \\
\hline & & & \multirow{2}{*}{ General Total } & No & 731 & 544 & 1275 & 100 \\
\hline & & & & $\%$ & 57 & 43 & & \\
\hline
\end{tabular}

As showed in Table 2a and Figure 2, the dominant learning styles for Turkish geography undergraduates were respectively listed by assimilating (42\%), converging (39\%), diverging $(12 \%)$ and accommodating (7\%). the assimilating was the most preferred learning style of Turkish geography undergraduates in three of geography departments (Atatürk University, Ondokuz Mayıs University, Kocatepe University) and in five of geography teaching departments (Gazi University, Dicle University), whereas in the other departments, converging was favored over the other styles by a small margin (Figure 3). Furthermore, in all Turkish universities, the assimilating and converging learning styles were favored by similar percentages of students, and two thirds of respondents were in either the assimilating cohort or the converging cohort. In a similar manner, Healey and colleagues (2005) evaluating the LSI scores of 932 respondents studying in 12 universities in the USA, UK, Australia and New Zealand reported that the assimilating learning style was preferred by $45 \%$ of Western geography undergraduates. The ratios of the other learning styles were ranked $24 \%$ for converging, $17 \%$ for diverging and $14 \%$ for accommodating, respectively (Table 2 b, Figure 2).

Table 2a. Preferred learning styles of Turkish geography undergraduates

\begin{tabular}{|c|c|c|c|c|c|c|c|c|}
\hline \multirow[b]{3}{*}{ University } & \multicolumn{8}{|c|}{ Kolb's Learning Styles } \\
\hline & \multicolumn{2}{|c|}{ Diverging } & \multicolumn{2}{|c|}{ Assimilating } & \multicolumn{2}{|c|}{ Converging } & \multicolumn{2}{|c|}{ Accommodating } \\
\hline & No & $\%$ & No & $\%$ & No & $\%$ & No & $\%$ \\
\hline 1-Ankara University & 10 & 10 & 39 & 39 & 44 & 44 & 7 & 7 \\
\hline 2-Atatürk University & 13 & 9 & 73 & 48 & 51 & 34 & 14 & 9 \\
\hline 3-Ondokuz Mayıs University & 24 & 14 & 78 & 46 & 62 & 37 & 6 & 4 \\
\hline 4-Onsekiz Mart University & 19 & 14 & 53 & 39 & 58 & 43 & 6 & 4 \\
\hline 5-Kocatepe University & 14 & 7 & 96 & 50 & 75 & 39 & 6 & 3 \\
\hline 6-Gazi University & 8 & 8 & 45 & 46 & 42 & 42 & 4 & 4 \\
\hline 7-Atatürk University & 28 & 15 & 66 & 36 & 68 & 37 & 24 & 13 \\
\hline 8-Dicle University & 17 & 26 & 23 & 35 & 20 & 31 & 5 & 8 \\
\hline 9-Dokuz Eylül University & 11 & 10 & 40 & 37 & 47 & 44 & 9 & 8 \\
\hline 10-Onsekiz Mart University & 10 & 14 & 27 & 39 & 28 & 40 & 5 & 7 \\
\hline All universities & 154 & 12 & 540 & 42 & 495 & 39 & 86 & 7 \\
\hline
\end{tabular}

*See Table 1 for names of faculties

Table 2b. Preferred learning styles of western geography undergraduates in Healey et al. (2005, p.36)

\begin{tabular}{lrrrrrrrrrr}
\hline & \multicolumn{1}{c}{ Divergers } & \multicolumn{4}{c}{ Kolb's Learning Styles } & \multicolumn{4}{c}{ Assimilators } & \multicolumn{2}{c}{ Convergers } & Accommodators & \multicolumn{2}{c}{ All students } \\
& No & $\%$ & No & $\%$ & No & $\%$ & No & $\%$ & No & $\%$ \\
\hline All countries & 158 & 17 & 416 & 45 & 224 & 24 & 134 & 14 & 932 & 100 \\
Australia & 22 & 18 & 57 & 48 & 25 & 21 & 15 & 13 & 119 & 100 \\
New Zealand & 67 & 18 & 150 & 39 & 98 & 26 & 66 & 17 & 381 & 100 \\
UK & 28 & 10 & 147 & 52 & 77 & 27 & 32 & 11 & 284 & 100 \\
US & 41 & 28 & 62 & 42 & 24 & 16 & 21 & 14 & 148 & 100 \\
\hline
\end{tabular}




\section{F.Ü. Sosyal Bilimler Dergisi 2015-25/1}

If the countries were evaluated individually, it was observed that for universities in the UK and US, the assimilating learning style was predominant, with ratios ranging from $39 \%$ to $55 \%$, whereas the dominant learning style for students of the Curtin University in Australia was the converging style, and the diverging style was preferred those of the Waikato University in New Zealand. The accommodating group (14\% of all sample) was never the dominant group in nine of the 12 Western universities, and this learning style was prefered by the smallest percentage $(7 \%)$ of students in all Turkish universities. However, the percentage (9\%) of the accommodating learners in the departments of geography teaching was almost double the percentage $(5 \%)$ of those who were studying in the department of geography. Furthermore, the percentage of accommodating for the Kazım Karabekir Faculty of Education rises to $13 \%$ and this value very close to percentage of Western accommodating (14\%) in Healey et al. (2005).

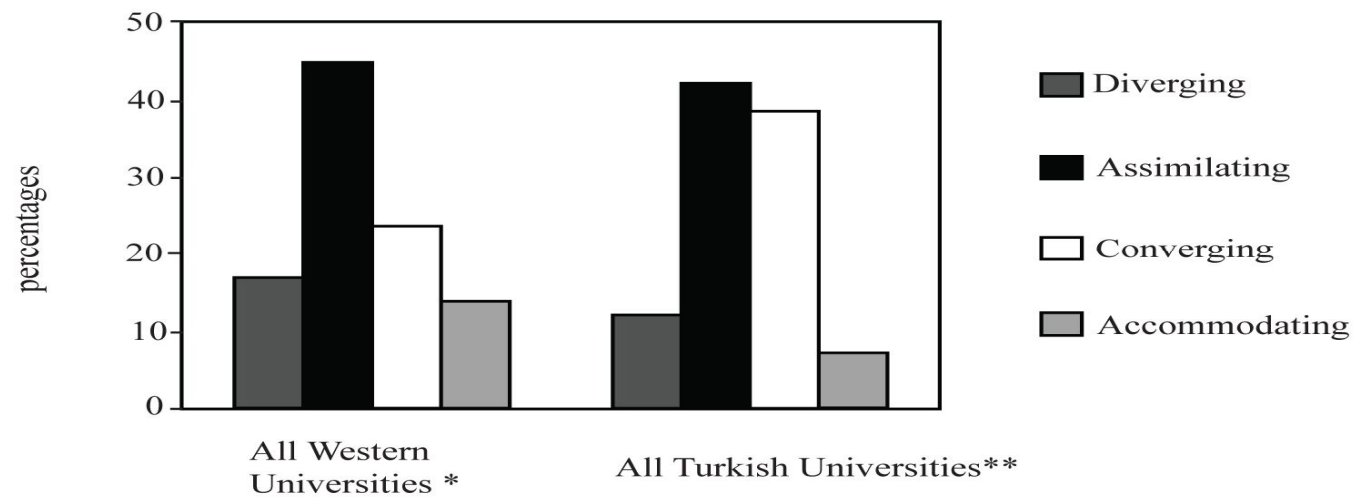

Figure 2. Kolb learning style preferences of geography undergraduates in Healey et al., 2005*, and in Turkish Universities**.

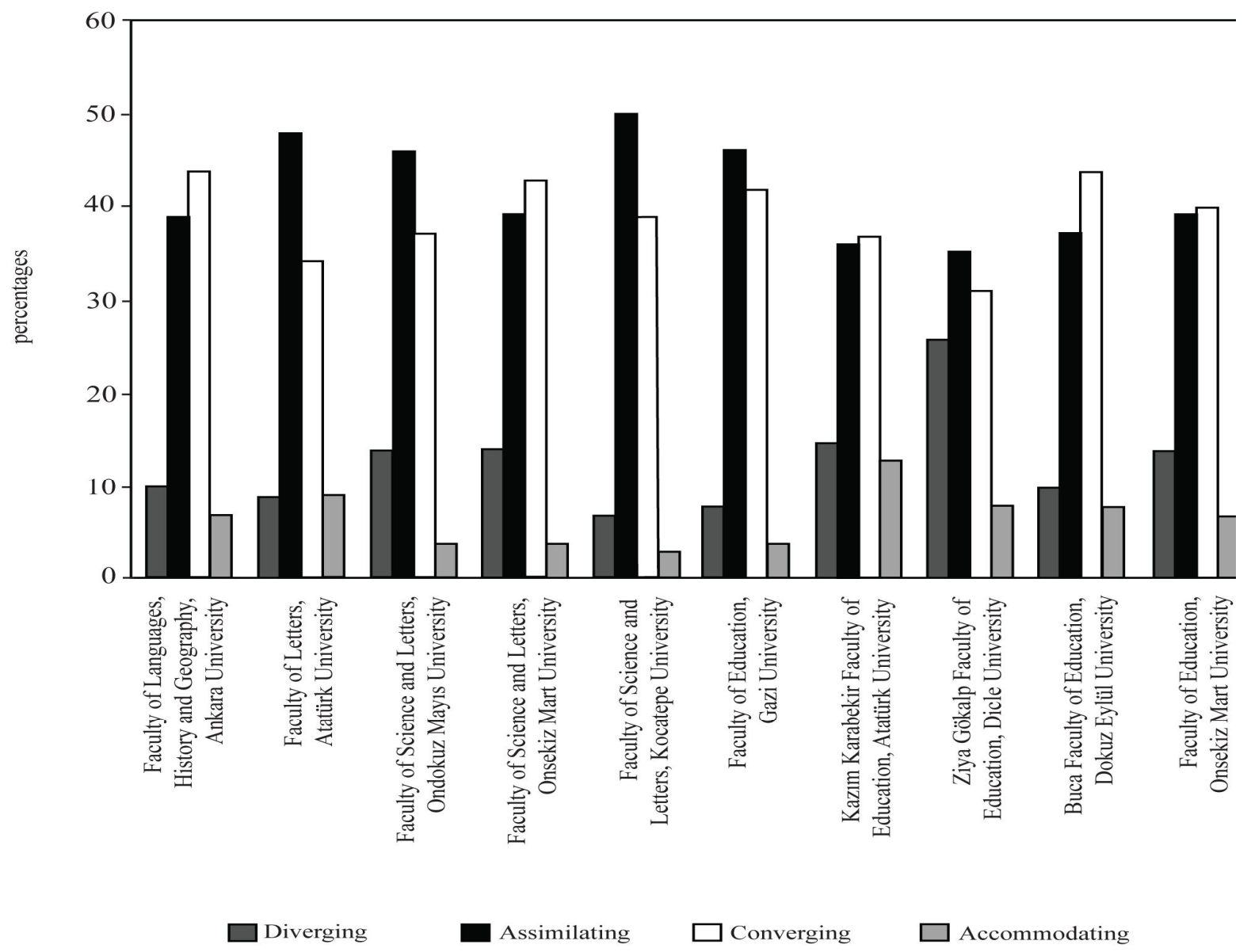

Figure 3. Kolb learning style preferences of Turkish geography undergraduates 
However, Healey and colleagues reported that in the Waikato University wherein mostly of respondents were human geographers exhibited the lowest percentage of assimilators, the highest percentage of accommodating groups, and one of the highest percentages of diverging group. They suggested that this could be related with the fact that most of the social science disciplines characterized by a predominance of accommodating and diverging learning styles (Healey et.al., 2005).

As shown in Table 3a, there are significant differences between the predominant learning styles of Turkish geography undergraduates within 10 departments. The main contributors to the Chi-square statistic come from the high percentage of assimilating and converging cohorts and the low percentage of diverging and accommodating cohorts in each of the departments. Nevertheless, the results of the one-way ANOVA in Table 4 show that there was no significant difference in the learning styles between the geography departments in Turkey ( $F$ value 0.076 and $P$ value 0.517 ), that is, the distribution of undergraduates' learning styles in all Turkish geography departments is similar to one another.

Table 3a. Chi Square tabulation results of Turkish geography undergraduates

\begin{tabular}{llll}
\hline Chi Square Tabulation & $\mathbf{X}^{\mathbf{2}}$ & Probability & Accept/Reject Ho \\
\hline All learning styles All universities & 55.20 & 0.001 & Reject \\
All learning styles Gender & 4.19 & 0.241 & Accept \\
All learning styles Age & 29.93 & 0,000 & Reject \\
All learning styles year of study & 18.58 & 0,029 & Reject \\
\hline
\end{tabular}

Although there were significant international differences in the predominant learning styles of Western geographers in four countries (Table 3b), when the data were aggregated to the country level, it was observed that there were significant differences in the distribution of learning styles within Australia and New Zealand, while intranational differences in the UK and USA were not significant (Healey et al. 2005).

Table 3b. Chi Square tabulation results of western geography undergraduates in Healey et al. (2005, p.37)

\begin{tabular}{lccc}
\hline Chi Square Tabulation & $\mathbf{X}^{\mathbf{2}}$ & Probability & Accept/Reject Ho \\
\hline All learning styles All universities & 77.3 & 0,000 & Reject \\
All learning styles Gender & 7.6 & 0,055 & Accept \\
All learning styles Age & 15.4 & 0,017 & Reject \\
All learning styles All countries & 35.2 & 0.000 & Reject \\
All learning styles Australian universities & 14.4 & 0.026 & Reject \\
All learning styles New Zealand universities & 21.2 & 0.002 & Reject \\
All learning styles UK universities & 3.6 & 0.073 & Accept \\
All learning styles US universities & 3.3 & 0.770 & Accept \\
\hline
\end{tabular}

Table 4. ANOVA results for key demographics

\begin{tabular}{|c|c|c|c|c|}
\hline & Sum of Squares & $\mathrm{df}$ & $\mathrm{F}$ & Probability \\
\hline \multicolumn{5}{|l|}{ University } \\
\hline Between Groups & 7.77 & 9 & 1.39 & .186 \\
\hline Within Groups & 778.88 & 1265 & & \\
\hline Total & 786.59 & 1274 & & \\
\hline \multicolumn{5}{|l|}{ Age } \\
\hline Between Groups & 1.51 & 3 & .81 & .487 \\
\hline Within Groups & 785.09 & 1271 & & \\
\hline Total & 786.59 & 1274 & & \\
\hline \multicolumn{5}{|l|}{ Year of study } \\
\hline Between Groups & 1.37 & 4 & .55 & .696 \\
\hline Within Groups & 785.22 & 1270 & & \\
\hline Total & 786.59 & 1274 & & \\
\hline
\end{tabular}

2- Comparison of the learning styles of Turkish geography undergraduates based on gender, age, and year of study.

As shown in Table 5, the assimilating was the dominant learning style of $41 \%$ of male 


\section{F.Ü. Sosyal Bilimler Dergisi 2015-25/1}

undergraduates and $45 \%$ of female undergraduates. The converging was the dominant learning style of $37 \%$ of male undergraduates and $39 \%$ of female undergraduates. Consistent with the findings of Healey et al., (2005), there was no significant difference between the learning styles of male and female Turkish geography undergraduates, according to the Chi-square results (Table 3a, Table 3b).

Table 5. Kolb's learning styles of the Turkish geography undergraduates according to key demographics

\begin{tabular}{|c|c|c|c|c|c|c|c|c|c|c|}
\hline \multirow{3}{*}{ Key demographics } & \multicolumn{8}{|c|}{ Kolb's Learning Styles } & \multicolumn{2}{|c|}{ In all students } \\
\hline & \multicolumn{2}{|c|}{ Diverging } & \multicolumn{2}{|c|}{ Assimilating } & \multicolumn{2}{|c|}{ Converging } & \multicolumn{2}{|c|}{ Accommodating } & \multirow[b]{2}{*}{ No } & \multirow[b]{2}{*}{$\%$} \\
\hline & No & $\%$ & No & $\%$ & No & $\%$ & No & $\%$ & & \\
\hline \multicolumn{11}{|l|}{ Gender } \\
\hline Man & 98 & 13 & 298 & 41 & 282 & 37 & 53 & 7 & 731 & 57 \\
\hline Female & 56 & 10 & 242 & 45 & 213 & 39 & 33 & 6 & 544 & 43 \\
\hline \multicolumn{11}{|l|}{ Age groups } \\
\hline $18-20$ & 18 & 17 & 36 & 34 & 49 & 46 & 3 & 3 & 106 & 8 \\
\hline $21-22$ & 81 & 10 & 46 & 29 & 39 & 24 & 6 & 4 & 804 & 63 \\
\hline $23-24$ & 44 & 17 & 96 & 36 & 98 & 37 & 25 & 10 & 263 & 21 \\
\hline $25+$ & 11 & 11 & 41 & 40 & 37 & 36 & 13 & 13 & 102 & 8 \\
\hline \multicolumn{11}{|l|}{ Year of study } \\
\hline 1 & 46 & 12 & 154 & 40 & 169 & 43 & 20 & 5 & 389 & 31 \\
\hline 2 & 37 & 11 & 159 & 47 & 123 & 37 & 18 & 5 & 337 & 26 \\
\hline 3 & 24 & 10 & 97 & 43 & 90 & 40 & 14 & 6 & 225 & 18 \\
\hline 4 & 29 & 12 & 102 & 44 & 85 & 37 & 17 & 7 & 233 & 18 \\
\hline $5 *$ & 18 & 20 & 28 & 31 & 28 & 31 & 17 & 19 & 91 & 7 \\
\hline
\end{tabular}

*The respondents in this grade level are from only the faculties of education, because the period of study is five years in schools of education whereas it is four years in the other faculties in the sample

The Chi-square statistic for age and year of study was showed a significant difference (Table 3a). Although the four learning styles of Kolb were observed in all age groups and all year-of-study groups, the percentages of students in the assimilating and converging cohorts was greater than those in the diverging and accommodating cohorts. However, the ANOVA results show that there was no significant difference between age groups or year-of-study groups (Table 4). As shown in Table 5, the distribution of learning styles in each age group and in each study years are similar to one another. Also Healey et al. (2005) proved that there was a significant difference within age groups using the Chi-Square test. They stressed that more of diverging and accommodating learning styles are found among students aged 21 and over than among younger students. They went on to stress that 'the students were not all at the same stage in their geographical experience though most are in the early stages of studying geography at university, pre-university experience varies (p. 35).' Therefore, the situation may be complicated with regard to making comparisons for age and year-of-study.

\section{DISCUSSION}

It is expected that the results of the present study, related to the learning styles of geography undergraduates in Turkey, which is classified as a non-Western country in some research (e.g. Hofstede, 2001; Javidan et al. 2006) on culture, will contribute towards filling the gap in the literature on the learning styles of geographers and culture. By comparing our findings with those obtained in a previous cross-cultural study of the learning styles of Western geography undergraduates (Healey et al. 2005), we have drawn the following conclusions:

- Kolb's four learning styles were found among the geography undergraduates.

- $81 \%$ of Turkish geography undergraduates in the present study and $69 \%$ of the Western geography undergraduates in Healey et al. (2005) preferred either assimilating or converging learning styles.

- The learning style least preferred by geography undergraduates was that of accommodating.

- When the data were aggregated to the country level, it was observed that there were significant differences in the distribution of learning styles between universities in Australia and 
New Zealand, while the differences between those in the UK, US and Turkey were not significant. According to the results of both studies, there is not significant the difference between genders in learning styles of geography undergraduates.

- According to the results of both studies, the difference in learning styles of geography undergraduates within age groups is significant, whereas the ANOVA results of the Turkish sample indicated that there was no significant difference between age groups.

- The majority of the geography undergraduates in the Western sample were in the early stages of their university courses, so the results of both studies were not compared with regard to year-of-study. However, according to the results obtained from the Turkish sample, there was a significant difference within year-of-study groups, whereas there was no significant difference between these groups, according to the ANOVA results.

The results of the present study have been indicated that the learning styles of geography undergraduates in Turkey have many similarities to those of their Western counterparts. Both studies comprised a substantial empirical data set examined using inferential statistics. Nevertheless, through the findings of both studies it would not be correct to claim that the dominant learning style of geographers is assimilating or converging. Therefore, these findings must be supported by further studies on the learning styles of geographers, or the effect of culture on their learning styles.

Learning styles and learning preferences are not constant and, indeed, change over time (Kolb \& Kolb, 2009). However, Nulty and Barrett (1996) cautioned that the learning style grouping should not be taken as an absolute representation of a particular student population, because different teaching strategies and discourse modes may be adopted that are not traditional to that discipline. However, it is important to account for learners' different learning styles and their learning preferences in the planning of learning and teaching processes. Smith (2002) argued that an important benefit of using Kolb with classes is in raising student awareness of their own position.

The assimilating and converging learning styles favored by the majority of the geography undergraduates are located in the south of Kolb's Learning Styles Grid. Therefore, most of these students tend to perceive information in the $\mathrm{AC}$ dimension and to process or to transform information either through $\mathrm{AE} / \mathrm{RO}$.

This type of learner typically relies on systematic planning, develops theories to solve problems, and needs time to analyze the information presented. The dominant learning abilities of assimilating learning styles are abstract conceptualization and reflective observation. In formal learning situations, people with this style prefer readings, lectures, exploring analytical models, and having time to think things through.

An individual with a converging style also has $\mathrm{AC}$ and $\mathrm{AE}$ as dominant learning abilities. People with this learning style are best at finding practical uses for ideas and theories. They have the ability to solve problems and make decisions based on finding solutions to questions or problems. In formal learning situations, people with this style prefer to experiment with new ideas, simulations, laboratory assignments and practical applications.

Geography can be thought of as offering a broad, general education, covering a breadth of academic materials, combined with hands-on field and laboratory studies (Healey et al. 2005). Due to these disciplinary specifications, it can be expected that the dominant learning styles of geographers is either converging in their comfort zone when dealing with the application of concepts and ideas or accommodating in their comfort zone when offered the opportunity for hands-on experience. It is therefore interesting that, as noticed by Healey et al. (2005), some $45 \%$ of the geographers in the Western sample and $42 \%$ of the geographers in the Turkish sample favored the assimilating style. A total of $24 \%$ of the geographers in the Western sample and $39 \%$ of the geographers in the Turkish sample favored the converging learning style. The lower percentage 


\section{F.Ü. Sosyal Bilimler Dergisi 2015-25/1}

in the Western sample compared to the Turkish sample may be related to the fact that Western respondents were in the early stages of their geography studies. Because educational experiences in an academic discipline shape to people's individual learning styles by instilling positive attitudes toward specific sets of learning skills and by teaching students how to learn (Kolb \& Kolb, 2009).

Joy and Kolb (2009) showed that there are relationships between learning style and culture of birth and residence. Some cross-cultural studies (e.g. Hoppe, 1990; Hoftstede \& McCrae, 2004; Javidan et al. 2006; Joy \& Kolb,2009; Holtbrügge \& Mohr, 2010) have indicated that Turkey is located in quite the opposite cultural cohort to the Western countries studied by Healey et al. (2005). Nevertheless, the results of the present study have shown that Turkish geography undergraduates have many similarities to their Western counterparts with regard to learning styles. This may be related to implications of the educational policies adopted since the foundation of the Republic of Turkey. If we review the educational history of Turkey, we can see some major developments and transformations.

The Republic of Turkey was established after the Ottoman Empire had attempted to adapt to the Western model in many aspects, such as administrative, legal, social and cultural life and education. In the process of restructuring the education system of Turkey, it was referenced in the views of the world-renowned education authorities, such as John Dewey, Alfred Kühne, Omer Buyse, and Albert Malche (Reisman, 2007). Following the university reform in 1933, new universities, faculties and departments were founded in Turkey. Turkey's first department of geography was established at the Istanbul Dar-ül Fünun in 1915, approximately after 16 years than the first modern department of geography was founded by Halford Mackinder at Oxford (Sidaway \& Jonston, 2007). Professor E. Obst, who was invited from Germany by the government in 1915, directed the establishment of the Institute of Geography at the University of Istanbul. Subsequently, two professors, T. H. Lefebvre and E. Chaput, were invited from France (Koçman \& Sütgibi, 2004). The Institute of Geography at Istanbul University was the only establishment active in this field until the Department of Geography at the Faculty of Humanities in Ankara was opened in 1935. Furthermore; and this second department of geography was opened under the chairmanship of German professor Herbert Lois (Widmann, 2000). The academic style and fields of expertise of the foreign staff of the earlier years, and those educated by these individuals, had a significant effect on the education programs in the years to follow. Not only foreign professors were assigned to lecture at these newly established universities both also Turkish students were sent abroad for postgraduate education. There were 180 academic staff at Istanbul University in 1933, and 138 of them was Turkish and 42 foreign. However, the heads of 27 departments were Turkish while the heads of 38 departments were foreign (Widmann, 2000). Of the foreign professors working in the Faculty of Humanities, which had opened in 1935, 11 were German, three were French, one was Hungarian, one was British and one was Austrian (Çelebi, 2003).

In addition to these developments, as in many other countries, the effect of globalization on education in Turkey cannot be ignored. However, some recent studies have investigated global trends with respect to learning style preferences. For example, Barron and Arcodia (2002) explored possible links between ethnic origin and learning style preference, with regard to students of the Confucian Heritage Culture (CHC) who were majoring in hospitality and tourism management at an Australian university. According to this study, the learning styles of CHC students were compatible with those of Western students, and furthermore, these students changed their approaches to learning, depending on their academic environment. In another study, Yamamura and Stedham (2004) also reported statistical evidence that indicated that peculiar traits of cultural dimensions for students from Eastern countries have been westernized over time. Also Turkey is in the process of integration with the European Union (EU) on many issues such as education. It is considered that the EU integration process has made an impact on many subjects, such as the curriculum and educational philosophies, teaching methods and techniques, the training of staff or lecturers and the teaching of students at all levels of education, from primary school through to college. In this context, this process may westernize to learning styles of students over time. 


\section{CONCLUSIONS}

For $21^{\text {st }}$ century geographers, the knowledge of geography alone will not be sufficient to make them ideal candidates for positions in the global business world. In addition, geographers must possess the skills to apply their particular subject knowledge as they enter the global job arena (Whalley, Saunders, Lewis, Buenemann, \& Sutton, 2011). Therefore, the important aspects of field classes and applications, especially as related to the geography curriculum in higher education, must be organized in such a way as to make the students active participants in the teaching and learning environments.

Modern geography is a positive science that adopts inductive and deductive reasoning. Hypothesis generation, test data, statistical and general analysis and reporting are processes applied by geographers for describing the places of the world (Kent, Gilbertson, \& Hunt, 1997). Therefore, Kolb's ELT is extremely compatible with modern geography that, as a discipline, emphasizes the system and the processes of the scientific method. As suggested by Healey et al. (2005), teachers should encourage their students to engage in all four stages of the learning cycle (Table 6).

As relevant, Healey \& Jenkins (2000) provided examples of use of the Kolb learning cycle as a framework for practical and field class experiences. 'Experiential learning is a process of constructing knowledge that involves a creative tension among the four learning modes that is responsive to contextual demands. This process is portrayed as an idealized learning cycle or spiral where the learner "touches all the bases"-experiencing, reflecting, thinking, and acting - in a recursive process that is responsive to the learning situation and what is being learned. Immediate or concrete experiences are the basis for observations and reflections. These reflections are assimilated and distilled into abstract concepts from which new implications for action can be drawn. These implications can be actively tested and serve as guides in creating new experiences (Kolb \& Kolb, 2009, p.5)'. Kolb's theory can be applied by using proper teaching methods and techniques, and by systematically engaging the students in this four-stage learning cycle that includes concrete experience, reflective observation, abstract conceptualization and active experimentation in any course, in any academic year or semester (Table 6, Figure 5).

Table 6. Activities associated with Kolb's learning modes

\begin{tabular}{llll}
\hline \multicolumn{1}{c}{ Concrete Experience } & \multicolumn{1}{c}{ Reflective Observation } & Abstract Conceptualization & \multicolumn{1}{c}{ Active Experimentation } \\
\hline $\begin{array}{l}\text { Lecture examples } \\
\text { Laboratories } \\
\text { Readings }\end{array}$ & & Lecture & Lecture examples \\
Fieldwork & & Text readings & Laboratories \\
& & & \\
Simulations & & Projects & Fieldwork \\
Observations & Thought questions & Model building & Projects \\
Films & Brainstorming & Model Critiques & Case studies \\
Problem sets & Discussions & Papers & \\
& Logs & Analogies & \\
\hline
\end{tabular}

Source: Adapted from Kolb (1984) and Svinicki \& Dixon (1987), but reorganized to highlight in italics activities that are said to be able to fall under two or more learning styles (Bergsteiner, Avery, \& Neumann, 2010, p. 40). 


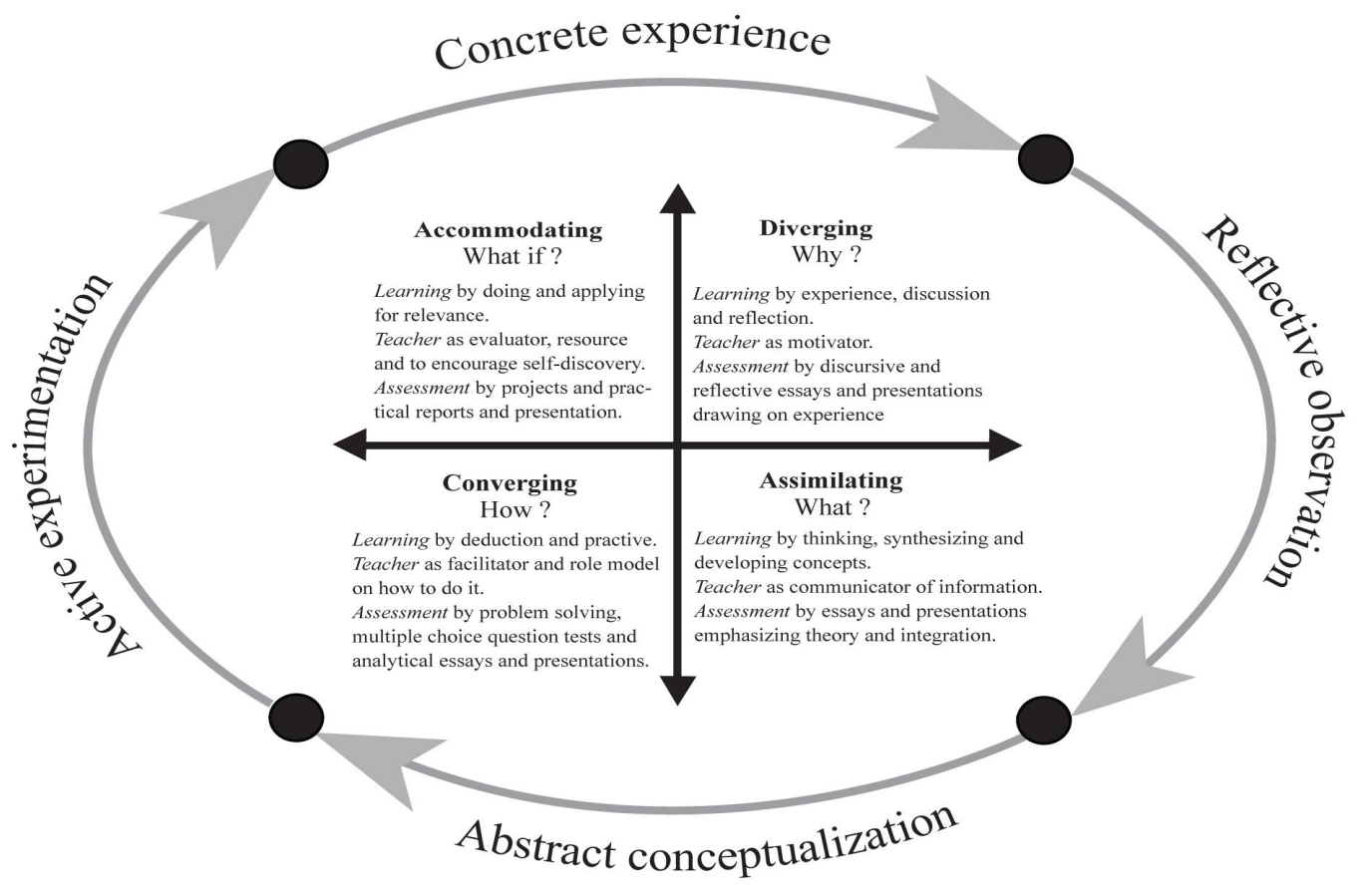

Figure 5. Teaching, learning and assessment activities matches to learning styles by adapted from Kolb 1984, Healey et al.,2005 (Özdemir \& Kesten, 2012).

It is hoped that the findings of this first comprehensive study on the learning styles of Turkish geographers will contribute to knowledge on geographer's learning styles and cross-country differences, and it accordingly inspires questions for future research, such as the following:

- What are the dominant learning styles of geographers in another non-Western country?

- What are the predominant learning styles of geography lecturers at universities?

- How will be impact to academic success of their and attitudes of students to take into account students' learning style in learning environments?

\section{REFERENCES}

Apfelthaler,G., Hansen, K., Keuchel, S., Neubauer, M., Ong, S. H., Tapacha1, N., \& Mueller, M. (2005). Cross cultural learning styles in higher education. International Journal Of Learning, 12 (5), 247-257.

Aşkar, P., \& Akkoyunlu, B. (1993). Kolb learning style inventory. Education and Science, 87, 37-47.

Auyeung, P., \& Sands, J. (1996). A cross-cultural study of the learning style of accounting students. Accounting and Finance, 36 (2), 261-274. doi: 10.1111/j.1467-629X.1996.tb00310.x.

Barmeyer, C. I. (2004). Learning styles and their impact on cross-cultural training: An international comparison in France, Germany and Quebec. International Journal of Intercultural Relations, 28, 577-594. doi:10.1016/j.ijintrel.2005.01.011.

Barron, P., \& Arcodia, C. (2002). Linking learning style preferences and ethnicity: International students studying hospitality and tourism management in Australia. Journal of Hospitality, Leisure, Sport and Tourism Education, 1(2), 1-13.

Retrieved from http://espace.library.uq.edu.au/eserv.php?pid=UQ:8864\&dsID=Accepted Paper.pdf.

Becher, T., Trowler, P. R. (2001). Academic Tribes and Territories: Intellectual Enquiry and the Cultures of Disciplines. (Adobe Digital Editions version). Retrieved from http://ceps.pef.unili.si/knjiznica/ izbirni/D.c.\%202001\%20Becher\%20and\%20Towler_Academic\%20Tribes\%20and\%20Teritories.pdf. 
Bergsteiner, H., Avery, G. C., \& Neumann, R. (2010). Kolb's experiential learning model: critique from a modelling perspective. Studies in Continuing Education, 32(1), 29-46.

Boland, G., Sugahara, S., Opdecam, E., \& Everaert, P. (2011). The impact of cultural factors on students' learning style preferences: A global comparison between Japan, Australia and Belgium. Asian Review of Accounting, 19 (3), 243 - 265. doi: 10.1108/13217341111185155.

Bradbeer, B. (1999). Barriers to Interdisciplinary: disciplinary discourses and student learning. Journal of Geography in Higher Education, 23 (3), 381-396. doi:10.1080/03098269985326.

Cassidy, S. (2004). Learning styles: an overview of theories. Educational Psychology, 24 (4), 419-444.

doi: $10.1080 / 0144341042000228834$

Coffield, F. J., Moseley, D.V., Hall, E., \& Ecclestone, K. (2004). Should we be using learning styles? What research has to say to practice? (Adobe Digital Editions version).

Retrieved from http://itslifejimbutnotasweknowit.org.uk/files/LSRC LearningStyles.pdf

Cullen, D. J., Pearson, M., Saha, L. J., \& Spear, R. H. (1994). Establishing effective PhD supervisions. Canberra: AGPS.

Çelebi, N. (2003). Dil ve Tarih-Coğrafya Fakültesi'ndeki Mülteci Profesörler. (The Refugee Professors at the Faculty of Language, History and Geography). Ankara Üniversitesi Dil ve Tarih Coğrafya Fakültesi Dergisi, 43 (1), 259-272. Retrieved from http://dergiler.ankara.edu.tr/dergiler/26/1009/12247.pdf

De Bello, T.C. (1990). Comparison of eleven major learning styles models: variables, appropriate populations, validity of instrumentation, and the research behind them. Reading, Writing, and Learning Disabilities, 6(3), 203-222. doi:10.1080/0748763900060302.

Dunn, R., \& Dunn, K. (1993). Teaching secondary students through their individual learning styles. Boston: Allyn \& Bacon.

Dunphy, A., \& Spellman, G. (2009). Geography fieldwork, fieldwork value and learning styles. International Research in Geographical and Environmental Education, 18 (1), 19-28. doi: 10.1080/ 10382040802591522.

Entwistle, N. J. (1981). Styles of Learning and Teaching: An Integrated Outline of Educational Psychology for Students, Teachers and Lecturers. Wiley: Chichester.

Eaves, M. (2011). The relevance of learning styles for international pedagogy in higher education. Teachers and Teaching: Theory and Practice, 17 (6), 677-691. doi: 10.1080/13540602.2011.625143.

Felder, R. M., \& Silverman, L. K. (1988). Learning and teaching styles in engineering education. Engr. Education, 78 (7), 674-681.

Retrieved from http://www4.ncsu.edu/unity/lockers/users/f/felder/public/Papers/LS-1988.pdf

Fridland, G. H. (2002). Adult learning styles and cultural background: A comparison of the learning style preferences of American teachers of English as a second language and Chinese teachers of English as a foreign language. Unpublished doctoral dissertation, University of Memphis, TN. Retrieved from http://search.proquest.com/pqdtft/docview/305443559/fulltextPDF/13FE40DDA1A2D66A071/1?accountid= 16701

Gencel, I. E. (2007). Kolb'ün Deneyimsel Öğrenme Kuramına Dayalı Öğrenme Stilleri III' ün Türkçeye Uyarlama Çalışması. (The Turkısh adoptation study of Kolb' learning style inventory). Dokuz Eylül Üniversitesi Sosyal Bilimler Enstitüsü Dergisi, 9 (2), 120-140.

Retrieved from http://www.sbe.deu.edu.tr/dergi/cilt9.say\%C4\%B12/9.2\%20gencel.pdf

Given, B. K. (1996). Learning styles: a synthesized model. Journal of Accelerated Learning and Teaching, 21 (1-2), 11-43. Retrieved from http://ialearn.org/files jalt/jalt_21 1996_1\%20\%26\%202. pdf\#page $=11$

Hadfield, J. (2006). Teacher education and trainee learning style. RELC Journal, 37 (3), 367-386. doi: $10.1177 / 0033688206071320$ 
Healey, M., \& Jenkins, A. (2000). Learning cycles and learning styles: the application of Kolb's experiential learning model in higher education. Journal of Geography, 99, 185-195. doi:10.1080/ 00221340008978967.

Healey, M., Kneale, P., \& Bradbeer, J. (2005). Learning styles among geography undergraduates: an international comparison. AREA. 37 (1), 30-42. doi: 10.1111/j.1475-4762.2005.00600.x.

Holtbrügge, D., \& Mohr, A. T. (2010). Cultural determinants of learning style preferences. Academy of Management Learning \& Education, 9 (4), 622-637.

Retrieved from http://www.immagic.com/eLibrary/ARCHIVES/GENERAL/AOM_US/A101222H.pdf

Hofstede, G. (2001). Culture's Consequences: Comparing Values, Behaviors, Institutions and Organizations Across Nations. SAGE Publication, Tousand Oaks:California.

Hofstede, G., \& McCrae, R. R. (2004). Personality and Culture Revisited: Linking Traits and Dimensions of Culture. Cross-Cultural Research, 38 (1), 52-88. doi: 10.1177/1069397103259443

Hoppe, M. H. (1990). A comparative study of country elites: International differences in work-related values and learning and their implications for management training and development. Unpublished doctoral dissertation, University of North Caroline at Chapel Hill, NC.

House, R.J., Hanges, P.M., Javidan, M., Dorfman, P., \& Gupta, V. (2004). Culture, Leadership and Organizations: The GLOBE Study of 62 Societies, Sage: Thousand Oaks, CA.

İlhan, A., Gülersoy, A. E., \& Gümüş, N. (2013). Coğrafya bölümü ve coğrafya öğretmenliği anabilim dalı mezunlarının mezuniyet sonrası karşıllaştıkları istihdam sorunu. Electronic Turkish Studies, 8(9). 5851602.

Javidan, M., Dorfman, P.W., Sully de L. M., \& House, R. J. (2006). In the Eye of the Beholder: Cross Cultural Lessons in Leadership from Project GLOBE. Academy of Management Perspectives, 20 (1), 67-90. Retrieved from http://www.csus.edu/indiv/s/sablynskic/documents/GLOBEprojecteyeofthebeholder.pdf

Jonassen, H. D., \& Grobowski, B. L. (1993). Handbook of Individual Differences, Learning and Instruction. Hillsdale, NJ: Lawrence Erlbaum.

Joy, S., \& Kolb, D. A. (2009). Are there cultural differences in learning style? International Journal of Intercultural Relations, 33, 69- 85. doi:10.1016/j.jiintrel.2008.11.002.

Kayes, D. C. (2002). Experiential learning and its critics: preserving the role of experience in management learning and education. Academy of Management Learning and Education, 1 (2), 137-149.

Kazu, İ. Y. (2009). The effect of learning styles on education and the teaching process. Journal of Social Sciences, 5 (2), 85-94. Retrieved from http://perweb.firat.edu.tr/personel/yayinlar/fua _35/35_59283.pdf

Kefee, J. W. (1987). Learning Style Theory and Practice. Restan, Va: National Association of Secondary School Principals.

Kent, M., Gilbertson, D., \& Hunt, C. (1997). Fieldwork in Geography teaching: a critical review of the literature and approaches. Journal of Geography in Higher Education, 21(3), 313-332. doi:10.1080/ 03098269708725439 .

Koçman, A., \& Sütgibi, S. (2004). Geographical Education and Training at Turkish Universities. International Research in Geographical and Environmental Education, 13 (1), 97-102. doi: http://dx.doi.org/10.1080/10382040408668799

Kolb, D. A. (1981). Learning styles and disciplinary differences. (Adobe Digital Editions version). Retrieved from http://www.medicine.heacademy.ac.uk/static/uploads/workshop_resources/178/178 Learning styles and disciplinary difference.pdf.

Kolb, D. A. (1984). Experiential learning: Experience as the source of learning and development. Englewood Cliffs, NJ: Prentice-Hall. Retrieved from http://academic.regis.edu/ed205/Kolb.pdf 
A Comparative Study Regarding The Learning Styles of ...

Kolb, D. A., Boyatzis, R. E., \& Mainemelis, C. (1999). Experiential learning theory: Previous Research and New Directions. (Adobe Digital Editions version). pdf

Retrieved from http://www.d.umn.edu/ kgilbert/educ5165-731/Readings/experiential-learning-theory.

Kolb, A. Y., \& Kolb, D. A. (2005). The Kolb learning style inventory: Version 3.12005 technical specifications. (Adobe Digital Editions version). Retrieved from http://www.whitewater-rescue.com/support/ pagepics/lsitechmanual.pdf.

Kolb, A. Y., \& Kolb, D. A. (2009). Experiential Learning Theory: a dynamic, holistic approach to management learning, education and development. (Adobe Digital Editions version). Retrieved from http://learningfromexperience.com/media/2010/08/ELT-Hbk-MLED-LFE-website-2-10-08.pdf

Leigh, J. (2005). Developing the Wyndham Scheme: A case study of geography education in NSW, Australia. Geography Online, 5 (2). Retrieved from http://www.siue.edu/GEOGRAPHY/ONLINE/Leigh05. pdf.

Lemire, D. (1996). Using learning styles in education: research and problems. Journal of Accelerated Learning and Teaching, 21, 43-57.

Retrieved from http://ialearn.org/files jalt/jalt_21_1996_1\%20\%26\%202.pdf\#page=45

Mainemelis, C., Boyatzis, R. E., \& Kolb, D. A. (2002). Learning styles and adaptive flexibility: testing experiential learning theory. Management Learning, 33 (1), 5-33. doi: 10.1177/1350507602331001.

Massey, M. G., Kim, S. H., \& Mitchell, C. (2011). A study of the learning styles of undergraduate social work students. Journal of evidence-based social work, 8(3), 294-303. Doi:10.1080/15433714.2011.557977.

Nulty, D. D., \& Barrett, M. A. (1996). Transitions in students' learning styles. Studies in Higher Education, 21, 333-345. doi: 10.1080/03075079612331381251.

ÖSYM, (2011). 2009-2010 öğretim yllı yükseköğretim istatistikleri (Higher education statistics for 2009-2010 academic year) (Adobe Digital Editions version). Retrived from http://osym.gov.tr/belge/112038/2009-2010-ogretim-yili-yuksekogretim-istatistikleri-kit-.html.

ÖSYM, (2013). 2012-2013 öğretim yılı yükseköğretim istatistikleri. (Adobe Digital Editions version). http://www.osym.gov.tr/dosya/1-69412/h/21 yabanciogrenciuyruk.pdf.

Özdemir, N., \& Kesten, A. (2012). Sosyal bilgiler öğretmen adaylarının öğrenme stilleri ve bazı demografik değişkenlerle ilişkisi. Atatürk Üniversitesi Sosyal Bilimler Enstitüsü Dergisi, 16 (1), 361-377.

Reisman, A. (2007). Jewish Refugees from Nazism, Albert Einstein, and the Modernization of Higher Education in Turkey (1933-1945). Aleph, 7, 253-281. Retrieved from http://www.jstor.org/stable/40377865.

Sidaway, J. D., \& Johnston, R. J. (2007). Geography in higher education in the UK. Journal of Geography in Higher Education, 31 (1), 57-80. doi:10.1080/03098260601033027

Smith, J. (2002). Learning styles: fashion fad or lever for change? The application of learning style theory to inclusive curriculum delivery. Innovations in Education and Teaching International, 39, 63-70.

Svinicki, M. D., \& Dixon, N. M. (1987). The Kolb model modified for classroom activities. College Teaching, 35 (4), 141-146.

Whalley, W. B., Saunders, A., Lewis, R. A., Buenemann, M., \& Sutton, P. C. (2011). Curriculum Development: Producing Geographers for the 21st Century. Journal of Geography in Higher Education, 35 (3), 379-393. doi:10.1080/03098265.2011.589827

Widmann, H. (2000). Atatürk ve Üniversite Reformu (Atatürk and the University Reform). (Translated from French: Aykut Kazancıgil \& Serpil Bozkurt). İstanbul: Kabalcı Yayınevi.

Yamamura, J. H., \& Stedham, Y. (2004). National cultural characteristics: a comparison of gender differences in Japan and the U.S. (Adobe Digital Editions version). Retrieved from http://www.sba. muohio.edu/abas/2002/sanjose/Stedham_Stedham-\%20Yamamura\%20-\%20Hofstede-\%20Gender.pdf 


\section{F.Ü. Sosyal Bilimler Dergisi 2015-25/1}

Yamazaki, Y. (2005). Learning styles and typologies of cultural differences: A theoretical and empirical comparison. International Journal of Intercultural Relations, 29 (5), 521-548. Retrieved from http://learningfromexperience.com/media/2010/08/yoshi-typologies-of-cultural-differences.pdf

Zualkernan, I.A.; Allert, J., \& Qadah, G.Z. (2006). Learning styles of computer programming students: a Middle Eastern and American comparison. IEEE Transactions on Education, 49 (4), 443-450. 